\title{
PENGARUH PENYIPONAN TERHADAP PERTUMBUHAN IKAN LELE SANGKURIANG (Clarias gariepinus) PADA SISTEM BIOFLOK
}

\author{
(The Effect Of Penyiponan On The Growth Of Sangkuriang Catfish (Clarias \\ gariepinus) In Biofloc Systems)
}

\author{
Oka Herdelah $^{1}$, Nasir Ahmad ${ }^{1 *}$, Zulkhasyni $^{1}$, Andriyeni ${ }^{1}$ \\ ${ }^{1}$ Jurusan Budidaya Perairan, Fakultas Pertanian Universitas Prof.Dr.Hazairin,SH Bengkulu \\ Jl. Jend. Soedirman no. 184 Bengkulu \\ *Corresponding Author, Email: nasirahmad_22@yahoo.com
}

\begin{abstract}
This study aims to determine the effect of 0\%, 15\%, 30\%, 45\%, and 60\% penyiponan for the growth of sangkuriang catfish (Clarias gariepinus) in the biofloc system. The research was conducted from April to June 2016, located on Jl Bukit Barisan, Kelurahan Tengah Padang, Teluk Segara District, Bengkulu City. The design used was a completely randomized design (CRD) with 5 treatments and 3 replications. The treatment of bioflocting is used as follows: $P 1=0 \%$ penyiponan, $P 2=15 \%$ penyiponan, $P 3=30 \%$ penyiponan, $P 4=45 \%$ penyiponan, $P 5=60 \%$ penyiponan. The results of the study concluded that the impregnation of the growth of Sangkuriang Catfish (Clarias gariepinus) in biofloc systems had a very significant effect on the growth of absolute weight, absolute length, feed conversion, feed efficiency and survival of Sangkuriang Catfish (Clarias gariepinus) and best available on penyimponan $45 \%$ with a survival of $98.41 \%$, dissolved oxygen $5.5 \mathrm{mg} / \mathrm{L}$, TSS $0.225 \mathrm{ml} / \mathrm{L}$ and ammonia 3.65.
\end{abstract} Keywords: Sangkuriang Catfish, bioflok, penyiponan.

\section{ABSTRAK}

Penelitian ini bertujuan untuk mengetahui pengaruh penyiponan 0\%, 15\%, 30\%, 45\%, dan $60 \%$ untuk pertumbuhan ikan lele sangkuriang (Clarias gariepinus) pada sistem bioflok. Penelitian dilaksanakan pada bulan April sampai Juni 2016, yang berlokasi di Jl Bukit Barisan Kelurahan Tengah Padang Kecamatan Teluk Segara Kota Bengkulu. Rancangan yang digunakan adalah Rancangan Acak Lengkap (RAL) dengan 5 perlakuan dan 3 ulangan. Perlakuan penyiponan bioflok yang digunakan sebagai berikut : $P 1=$ penyiponan $0 \%, P 2=$ penyiponan $15 \%, P 3=$ penyiponan $30 \%, P 4=$ penyiponan $45 \%, P 5=$ penyiponan $60 \%$. Hasil penelitian menyimpulkan penyimponan terhadap pertumbuhan ikan Lele Sangkuriang (Clarias gariepinus) pada sistem bioflok berpengaruh sangat nyata terhadap pertumbuhan berat mutlak, panjang mutlak, konversi pakan, efisiensi pakan dan kelangsungan hidup Ikan Lele Sangkuriang(Clarias gariepinus) dan Penyimponan yang terbaik terdapat pada penyimponan 45\% dengan kelansungan hidup mencapai 98,41\%, oksigen terlarut 5,5 $\mathrm{mg} / \mathrm{L}$, TSS 0,225 $\mathrm{ml} / \mathrm{L}$ dan amonia 3,65.

Kata kunci: Ikan Lele Sangkuriang, bioflok, penyiponan

\section{PENDAHULUAN}

$\begin{array}{rcr}\text { Ikan } & \text { Lele Sangkuriang } & \text { (Clarias } \\ \text { gariepinus) } & \text { merupakan salah satu }\end{array}$ komoditas budidaya ikan air tawar di Indonesia yang bernilai ekonomis penting. Dalam upaya untuk meningkatkan jumlah produksi ikan Lele Sangkuriang diperlukan 


\section{DOI: https://doi.org/10.32663}

usaha budidaya secara intensif, sampai saat ini belum ada yang mecoba manfaatkan sistem bioflok dengan cara di sipon.

Bioflok dapat terbentuk jika terdapat bakteri pembentuk bioflok yaitu menggunakan mulase/tetesan tebu, bakteri tersebut yaitu bakteri heterotrof. Bakteri heterotrof dapat mengolah limbah menjadi bioflok. Bioflok mengandung $39-48 \%$ protein sehingga dapat dimanfaatkan sebagai pakan alami dan telah diaplikasikan pada ikan Lele (Widarnani, 2012), selain dapat memperbaiki kualitas air nutrisi bioflok juga dapat meningkatkan kecernaan pakan dengan aplikasinya melalui pakan (Salamah 2014). Teknologi bioflok merupakan salah satu alternatif dalam mengalasi masalah kualitas air dalam akuakultur yang diadaptasi dari teknik pengolahan limbah domestik secara konvensional (Avnimelech, 2006). Beberapa penelitian menunjukkan bahwa aplikasi teknologi bioflok berperan dalam perbaikan kualitas air, peningkatan biosekuriti, peningkatan produktivitas. peningkatan efisiensi pakan serta penurunan biaya produksi melalui penurunan biaya pakan.

Sistem heterotrofik mempunyai potensi untuk diterapkan dalam pemanfaatan limbah amonia pada pemeliharaan ikan (Gunadi \& Hafsaridewi, 2007). Komunitas bakteri yang terakumulasi di dalam sistem akuakultur heterotrofik akan membentuk flok (gumpalan) yang dapat dimanfaatkan sebagai sumber pakan untuk ikan. Salah satu jenis ikan yang dapat memakan komunitas mikroba dalam bioflok adalah ikan Lele.Teknologi Bioflok (Biofloc Technology, BFT) dalam akuakultur adalah memadukan teknik pembentukan bioflok tersebut sebagai sumber pakan bagi ikan
(Crab et al, 2007). Dalam penelitian ikan Lele pasti ada sisa pakan, fases, sedimen yang mengendap atau flok dan lainya maka dari itu harus mengukur Zat Padat Tersuspensi (TSS).

Zat Padat Tersuspensi (TSS) adalah padatan yang menyebabkan kekeruhan air, tidak terlarut dan tidak dapat langsung mengendap, terdiri dari partikel-partikel yang ukuran maupun beratnya lebih kecil dari sedimen, misalnya tanah liat, bahanbahan organik tertentu, sel-sel mikroorganisme, dan sebagainya

Teknologi probiotik merupakan salah satu alternatif dalam mengatasi masalah kualitas air dalam akuakultur yang diadaptasi dari teknik pengolahan limbah domestik secara konvensional (Avnimelech and Kochba, 2009). Beberapa penelitian menunjukkan bahwa aplikasi teknologi probiotik berperan dalam perbaikan kualitas air, peningkatan biosekuriti, peningkatan produktivitas. peningkatan efisiensi pakan serta penurunan biaya produksi melalui penurunan biaya pakan (Avnimelech and Kochba, 2009).

Sipon atau Shift Pond merupakan tindakan untuk membuang kotoran yang mengendap di dasar wadah ikan uji. Sipon wajib dilakukan dalam budidaya perikanan karena dapat mengurangi konsentrasi amonia dan nitrit yang ditimbulkan oleh penumpukan, kotoran ikan dan sisa pakan di dasar kolam. Penyiponan harus dilakukan secara teratur pada pembesaran ikan Lele Sangkuriang, Penelitian ini bertujuan untuk mengetahui pengaruh penyiponan $0 \%, 15 \%$, $30 \%, 45 \%$, dan $60 \%$ untuk pertumbuhan ikan Lele Sangkuriang (Clarias gariepinus) pada sistem bioflok.

\section{BAHAN DAN METODE}

Penelitian ini telah dilaksanakan selama 56 hari yang dimulai pada bulan 


\section{DOI: $\underline{\text { https://doi.org/10.32663 }}$}

April sampai bulan Juni 2016, yang berlokasi di Jl Bukit Barisan Kelurahan Tengah Padang Kecamatan Teluk Segara Kota Bengkulu. Alat yang digunakan adalah Timbangan, mistar, $\mathrm{pH}$ meter, thermometer celcius, DO meter, gelas ukur, wadah bok plastik, Plankton net ukuran 30$50 \mu \mathrm{m}$ dan aerator. Bahan yang digunakan adalah: Bibit ikan Lele Sangkuriang ukuran 5-7 cm/ekor, Pakan sebagai pakan ikan dengan Ukuran: Pakan $0.7 \mathrm{~mm}-1.0 \mathrm{~mm}$, Type Pellet, Protein min 39\%, Lemak min $5 \%$, Serat Kasar max 6\%, Abu max $16 \%$, Kadar Air max $10 \%$ dan Mulase atau probiotik.

Penelitian ini menggunakan Rancangan Acak Lengkap (RAL) dengan satu faktor yang terdiri dari lima perlakuan dengan tiga kali ulangan yaitu: $\mathrm{P} 1=$ Penyiponanan $0 \%, \mathrm{P} 2=$ Penyiponan $15 \%$, $\mathrm{P} 3=$ Penyiponan $30 \%$, P4= Penyiponanan $45 \%$, P5= Penyiponan $60 \%$. Data yang diperoleh diuji dengan analisis keragaman pada taraf $5 \%$ dan $1 \%$, apabila terdapat pengaruh nyata maka dilanjutkan dengan uji Beda Nyata terkecil (BNT) pada taraf $5 \%$ dan $1 \%$.

\section{Pelaksanaan Penelitian}

Persiapan dimulai dari menyiapkan alat dan bahan penelitian, pembersihan wadah, pengisian air, pemasangan wadah, menghitung formulasi pakan, menghitung mulase, proses adaptasi pemberian pakan pelet pada ikan uji.Wadah ikan uji dengan ukuran panjang $57.9 \mathrm{~cm}$ x lebar $28.8 \mathrm{~cm} \mathrm{x}$ tinggi $30 \mathrm{~cm}$ yang diisi air setinggi $20 \mathrm{~cm}$.

Penyiponan dilakukan dengan manual, dengan menggunakan plankton net ukuran 30-50 $\mu \mathrm{m}$. air disaring dengan jumlah yang telah ditentukan, setelah disaring air masukan kembali ke wadah ikan uji dan amoniak, fases atau kotoran yang di saring langsung di buang. Penyiponan di lakukan 7 hari sekali.

Jumlah ikan uji sebanyak 630 ekor dengan ukuran ikan 5- $7 \mathrm{~cm}$ dengan padat tebar ikan 42 ekor/wadah.

Pakan yang digunakan adalah pelet 1. Frekuensi pemberian pakan tiga kali sehari yaitu pada pukul $09.00,15.00$, dan 20.00 wib, dengan dosis 5\% dari berat biomassa ikan uji. Pakan diberikan dengan cara ditebar.

Ikan hanya memanfaatkan $22.2 \%$ nitrogen dalam pakan sedangkan sisanya diekskresi berupa NH4 atau N organik yang terdapat dalam feses dan residu pakan (Ebeling et al. 2006). Efisiensi, konversi mikroba diasumsikan $40-60 \%$, sehingga jumlah nitrogen yang terbuang dalam perairan dapat dihitung berdasarkan jumlah pakan, kandungan $\% \mathrm{~N}$ dalam pakan serta $\% \mathrm{~N}$ yang di ekskresi.

Pengukuran panjang dan berat ikan uji setelah masa adaptasi untuk pengamatan awal, selanjutnya akan dilakukan setiap 14 hari sekali sebanyak 5 kali pengamatan selama 56 hari penelitian.

Parameter kualitas air yang diamati yaitu derajat keasaman $(\mathrm{pH})$ dan $\mathrm{DO}$ dilakukan pada awal, tengah dan akhir penelitian, suhu air dilakukan tiga kali sehari yaitu pagi, siang dan sore hari, TSS dan amonia. dilakukan 2 x salama penelitian yaitu tengah dan akhir penelitian.

Parameter yang diamati adalah pertumbuhan ikan, yang meliputi berat mutlak, panjang mutlak, konversi pakan, efisiensi pakan, kelangsungan hidup dan Kualitas Air

\section{HASIL DAN PEMBAHASAN}

Rekapitulasi hasil analisis sidik ragam pengaruh penyiponan terhadap berat mutlak, panjang mutlak, konversi pakan, 


\section{DOI: $\underline{\text { https://doi.org/10.32663 }}$}

Efisiensi pakan dan kelansungan hidup pada sistem bioflok disajikan pada Tabel 1. ikan Lele Sangkuriang (Clarias gariepinus)

Tabel 1. Rekapitulasi Hasil Analisa Sidik Ragam Pengaruh penyiponan terhadap Pertumbuhan Ikan Lele Sangkuriang (Clarias Gariepinus)

\begin{tabular}{|c|c|c|c|}
\hline & & \multicolumn{2}{|c|}{ F table } \\
Parameter yang diamati & F hit & $5 \%$ & $1 \%$ \\
\hline Berat mutlak & $80.10(* *)$ & \multirow{2}{*}{3.48} & \multirow{2}{*}{5.98} \\
\hline Panjang mutlak & $21.78(* *)$ & & \\
\hline Konversipakan & $88.76(* *)$ & & \\
\hline Efiensi pakan & $170.23(* *)$ & \\
\hline Kelangsungan hidup & $8.26(* *)$ & & \\
\hline
\end{tabular}

Keterangan: $(* *)$ berpengaruh sangat nyata

Tabel 1. Memperlihatkan bahwa pengaruh penyiponan terhadap pertumbuhan ikan Lele Sangkuriang berpengaruh sangat nyata terhadap parameter berat mutla, panjang mutlak, Konversi pakan, efisiensi pakan dan kelansungan hidup.

Tabel 2.Rekapitulasi Hasil Uji BNT 5\% Pengaruh Penyiponan Terhadap Pertumbuhan Ikan Lele Sangkuriang.

\begin{tabular}{|c|c|c|c|c|c|}
\hline \multirow[b]{2}{*}{ Penyiponan } & \multicolumn{5}{|c|}{ Rata-Rata } \\
\hline & Berat & Panjang & $\begin{array}{c}\text { Konversi } \\
\text { Pakan }\end{array}$ & $\begin{array}{l}\text { Efesiensi } \\
\text { Pakan }\end{array}$ & $\begin{array}{c}\text { Kelangsungan } \\
\text { Hidup }\end{array}$ \\
\hline penyiponan $0 \%$ & $13.33 \mathrm{a}$ & $6.03 \mathrm{a}$ & $2.16 \mathrm{~d}$ & $38.06 \mathrm{a}$ & $88.89 \mathrm{a}$ \\
\hline penyiponan $15 \%$ & $13.75 \mathrm{a}$ & $6.27 \mathrm{ab}$ & $2.07 \mathrm{c}$ & $38.45 \mathrm{a}$ & $90.48 \mathrm{a}$ \\
\hline penyiponan $60 \%$ & $15.14 \mathrm{~b}$ & $8.03 \mathrm{bc}$ & $1.84 \mathrm{~b}$ & $37.91 \mathrm{~b}$ & $92.86 \mathrm{~b}$ \\
\hline penyiponan $30 \%$ & $16.33 \mathrm{c}$ & $8.63 \mathrm{c}$ & $1.84 \mathrm{~b}$ & $40.28 \mathrm{~b}$ & $97.62 \mathrm{c}$ \\
\hline penyiponan $45 \%$ & $19.28 \mathrm{~d}$ & $8.97 \mathrm{c}$ & $1.70 \mathrm{a}$ & $42.19 \mathrm{c}$ & $98.41 \mathrm{c}$ \\
\hline
\end{tabular}

Keterangan: Angka yang diikuti oleh huruf yang sama, berarti tidak berbeda nyata

\section{Pertumbuhan Berat Mutlak dan Panjang Mutlak}

Pertumbuhan merupakan perubahan ukuran tubuh yang dapat berupa baret atau panjang suatu organisme dalam waktu tertentu (Effendie, 2003). Prihadi (2007), menyatakan pertumbuhan dipengaruhi oleh beberapa faktor yaitu faktor dari dalam dan faktor dari luar, adapun faktor dari dalam meliputi sifat keturunan, ketahanan terhadap penyakit dan kemampuan dalam memanfaatkan makanan, sedangkan faktor dari luar meliputi sifat fisika, kimia dan biologi perairan sedangkan faktor makanan dan suhu perairan merupakan faktor utama yang dapat mempengaruhi pertumbuhan ikan. 


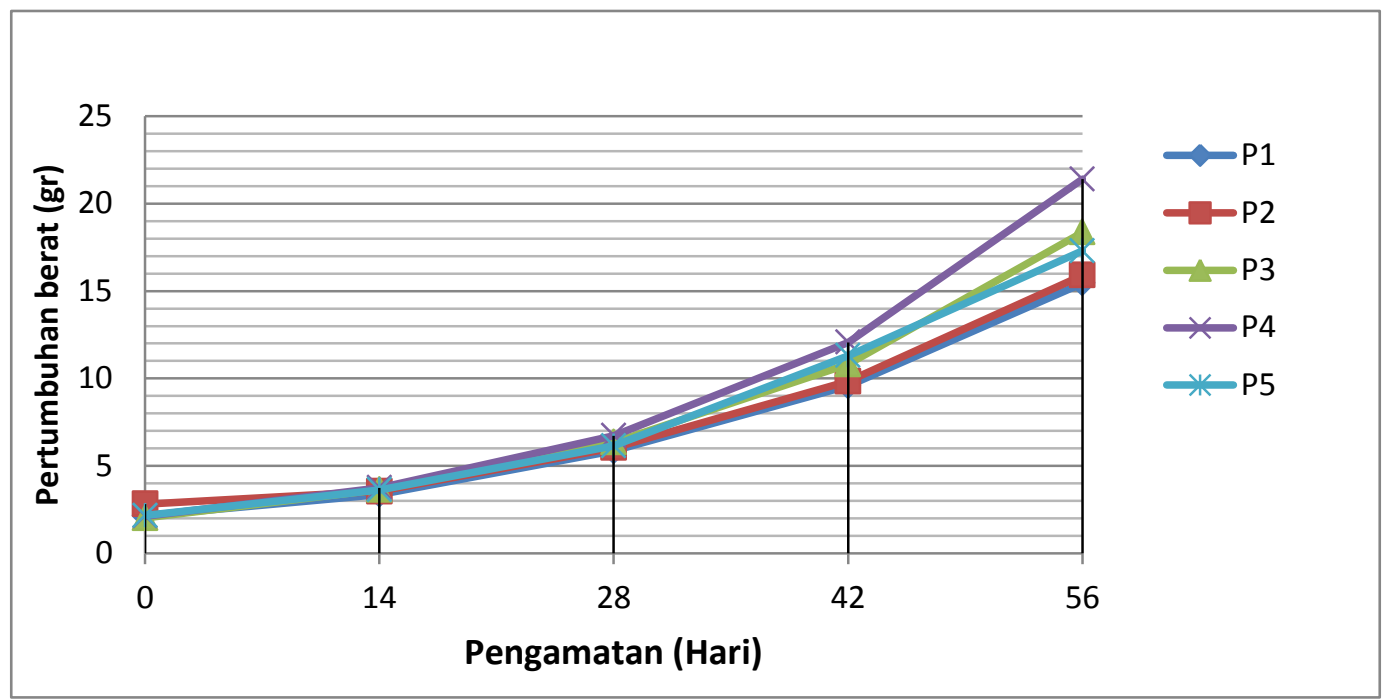

Grafik 1. Rata-rata pertumbuhan berat mutlak ikan lele Sangkuriang selama 56 hari

Berdasarkan grafik 1 menunjukkan terhadap lingkungan kemudian pada bahwa selama penelitian berat ikan Lele pengamatan hari ke 28, ke 42 sampai hari Sangkuriang dari masing-masing perlakuan ke 56 ikan Lele Sangkuriang mengalami terus mengalami kenaikan seiring dengan pertumbuhan yang signifikan.

bertambahnya umur ikan lele sangkuriang.

Berdasarkan Tabel 2 hasil uji BNT Rata-rata berat ikan Lele Sangkuriang 5\% terhadap pertumbuhan berat mutlak (Clarias gariepinis) Penyiponan 0\%, 15\%, menunjukkan bahwa rata-rata berat ikan $30 \%$, $45 \%$ dan $60 \%$ pada awal penebaran Lele Sangkuriang pada penyiponan $45 \%$ hari 0 ke 14 sampai hari 28 pertumbukan menunjukkan berat yang baik dibandingkan tidak terlalu jauh meningkat dimana ikan dengan penyiponan 30\%,60\%, 15\% dan Lele Sangkuriang (Clarias gariepinus) $0 \%$.

masih berada fase awal atau adaptasi

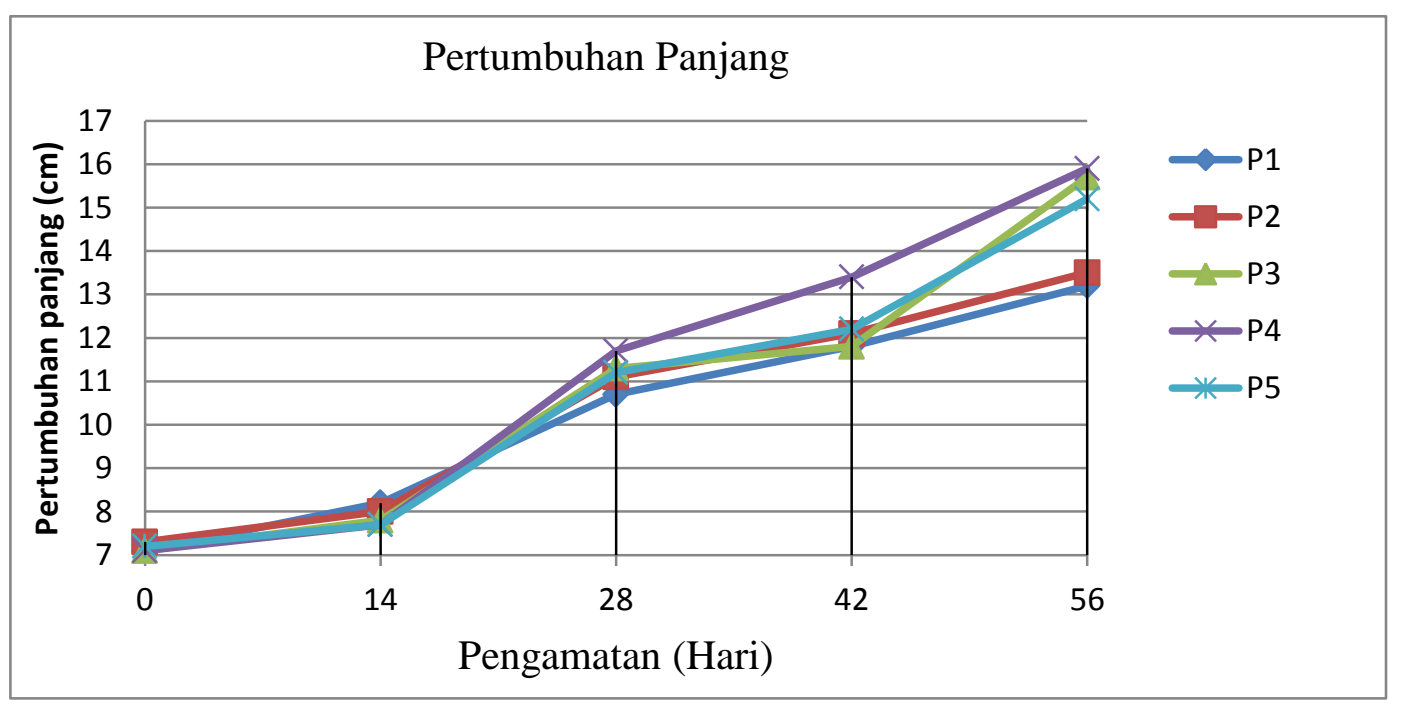

Grafik 2. Rata-rata pertumbuhan panjang mutlak ikan lele Sangkuriang selama 56 hari 


\section{DOI: $\underline{\text { https://doi.org/10.32663 }}$}

Berdasarkan grafik 2 bahwa masingmasing penyiponanan mengalami pertumbuhan panjang yang meningkat dimana rata-rata panjang ikan Lele Sangkuriang (Clarias gariepinus) penyiponan $0 \%, 15 \%, 30 \%, 45 \%$ dan $60 \%$ pada awal penebaran hari 0 sampai hari ke 14 belum mengalami pertumbuhan yang signifikan karena masih berada pada fase awal atau adaptasi dengan lingkungan dan makanan sedangkan pada hari ke 28 sampai hari ke 56 ikan Lele Sangkuriang (Clarias gariepinus) mengalami pertumbuhan yang signifikan.

Berdasarkan Uji Lanjut BNT (Tabel 2) menunjukan bahwa penyiponana terbaik untuk pertumbuhan panjang ikan Lele Sangkuriang terdapat pada penyiponan $45 \%$ dibandingkan dengan penyiponan $30 \%$, penyiponan $60 \%$, penyiponan $15 \%$ dan penyiponan $0 \%$.

Hendrawati, R (2011) menyatakan bahwa adanyan pengaruh yang berbeda terhadap pertumbuhan berat dan panjang ikan Lele Sangkuriang di sebabkan prosentase penyiponan yang berbeda karena berpengaruh terhadap kualitas air yang menghasilkan pertumbuhan yang berbeda pula.

Perbedaan peningkatan berat dan panjang tubuh benih Lele Sangkuriang pada kedua media budidaya (aplikasi probiotik dan tanpa probiotik), memang berpengaruh pada pertumbuhan ikan, hal itu cukup memberikan gambaran bahwa benih Lele Sangkuriang yang dipelihara dengan aplikasi probiotik mengalami pertumbuhan berat dan panjang yang lebih baik. Hal ini mengindikasikan bahwa pakan yang diberikan dan media pemeliharaan-nya mampu mendukung per-tumbuhan benih Lele Sangkuriang (Craigh dan Helfrich 2002).

\section{Konversi Pakan}

Berdasarkan Tabel 2 hasil uji BNT 5\% terhadap Konversi Pakan menunjukkan bahwa rata-rata konversi pakan ikan Lele Sangkuriang pada penyiponan $45 \%$ menunjukkan nilai terbaik dibandingkan dengan penyiponan $30 \%, 60 \%, 15 \%$ dan $0 \%$.

Bila nilai konversi pakan kecil maka kualitas pakan semakin baik begitu juga sebaliknya jika semakin tinggi konversi pakan maka makin rendah pula kualitas pakan yang digunakan (Djajasewaka, 1990), Konversi pakan adalah jumlah satu kilogram pakan dapat diubah menjadi satu kilogram daging ikan (Yulfiperius, 2014).

Adanya nilai konversi pakan yang berbeda-beda pada masing-masing penyiponan di sebabkan oleh kandungan protein hewani yang berbeda pada setiap penyiponan.. Menurut Peni, (1993); Sarwono, (1999); Kamil dkk., (2000) dalam Haryono (2008) Untuk memacu pertumbuhan ikan Lele Sangkuriang perlu disediakan pakan berprotein hewani yang tinggi karena sifatnya yang karnivora.

\section{Efisiensi Pakan}

Berdasarkan Tabel 2 hasil uji BNT 5\% terhadap Efisiensi Pakan pakan menunjukkan bahwa rata-rata Efisiensi Pakan ikan Lele Sangkuriang pada penyiponan $45 \%$ menunjukkan Efisiensi Pakan terbaik dibandingkan dengan penyimponan $30 \%, 60 \%, 15 \%$ dan penyiponan $0 \%$.

Tingkat efisiensi pakan di pengaruhi oleh faktor lingkungan, umur, dan bahan pakan yang digunakan (Yulfiperius, 2014). Menurut Hernowo dan Rachmatun (2008) dalam Mulis (2015), jika ketersediaan pakan selalu mencukupi maka tingkat keberhasilan pemeliharaan dapat mendekati 


\section{DOI: https://doi.org/10.32663}

$100 \%$, bahkan tidak ada yang mati atau hilang.

\section{Kelangsungan Hidup}

Pada Tabel 2 rata-rata tingkat kelangsungan hidup Lele Langkuriang menunjukan bahwa penyiponan terbaik terdapat pada perlakuan penyiponan $45 \%$ dibandingkan penyiponan $30 \%, 60 \%, 15 \%$ dan $0 \%$.

\section{Untuk mempertahankan} kelangsungan hidup dan pertumbuhan, maka diperlukan makanan yang memenuhi kebutuhan nutrisi ikan. Selanjutnya Rukmana dan Rahmat, (2003), menyatakan bahwa makanan yang dimakan oleh ikan digunakan untuk kelangsungan hidup selebihnya dimanfaatkan untuk pertumbuhan.

\section{Kualitas Air}

Nilai kisaran kualitas air selama penelitian dapat dilihat pada Tabel 3 .

Tabel 3. Nilai kisaran kualitas air pada masing-masing penyimponan

\begin{tabular}{|c|c|c|c|c|c|c|}
\hline \multirow{2}{*}{ Pengamatan } & \multirow{2}{*}{$\begin{array}{l}\text { Penyiponan } \\
(\%)\end{array}$} & \multicolumn{5}{|c|}{ Parameter Kualitas Air } \\
\hline & & Suhu $\left({ }^{\circ} \mathrm{C}\right)$ & $\mathrm{pH}$ & $\begin{array}{c}\text { Do } \\
(\mathrm{mg} / \mathrm{L})\end{array}$ & TSS (ml/L) & $\begin{array}{c}\text { Amonia } \\
(\mathrm{ml} / \mathrm{L})\end{array}$ \\
\hline \multirow{5}{*}{ Awal } & 0 & $27.1-28.3$ & $6.5-7.1$ & 4.5 & & \\
\hline & 15 & $26.8-28.1$ & $6.7-7.3$ & 4.4 & & \\
\hline & 30 & $27.5-28.4$ & $6.4-7.2$ & 4.7 & & \\
\hline & 45 & $26.6-28.0$ & $6.3-7.3$ & 4.5 & & \\
\hline & 60 & $26.1-27.8$ & $6.7-7.1$ & 4.6 & & \\
\hline \multirow{5}{*}{ Tengah } & 0 & 27.2-29.2 & $6.5-7.3$ & 4.7 & $0.371-0.305$ & 4.91 \\
\hline & 15 & $27.1-29.4$ & $6.5-7.3$ & 4.4 & $0.291-0.324$ & 4.41 \\
\hline & 30 & 27.4-29.5 & $6.3-7.3$ & 4.8 & $0.231-0.301$ & 4.23 \\
\hline & 45 & 26.7-29.1 & $6.6-7.5$ & 5.5 & $0.206-0.244$ & 3.65 \\
\hline & 60 & $26.5-29.3$ & $6.5-7.5$ & 5.2 & $0.157-0.193$ & 3.22 \\
\hline \multirow{5}{*}{ Akhir } & 0 & $26.1-28.1$ & $6.6-7.2$ & 4.7 & $0.331-0.402$ & 5.02 \\
\hline & 15 & $26.3-27.8$ & $6.3-7.5$ & 4.6 & $0.324-0.395$ & 4.64 \\
\hline & 30 & $27.2-27.6$ & $6.4-7.5$ & 4.6 & $0.246-0.280$ & 4.41 \\
\hline & 45 & $27.2-28.1$ & 6.4-7.4 & 5.1 & $0.232-0.273$ & 3.82 \\
\hline & 60 & $27.7-28.4$ & $6.5-7.5$ & 5.2 & $0.171-0.224$ & 3.56 \\
\hline
\end{tabular}


DOI: https://doi.org/10.32663

Pertumbuhan ikan Lele Sangkuriang (Clarias gariepenus) pada sistem bioflok kualitas air suhu, $\mathrm{pH}$, Do tidak berpengaruh sedangkan TSS dan ammonia sangat berpengaruh, selama penelitian TSS dan ammonia akan selalu meningkat jadi mengakibatkan kualitas air memburuk.. kisaran suhu dari awal pemeliharaan sampai akhir pemeliharaan adalah 26.1$29.5^{\circ} \mathrm{C}$, suhu yang optimum bagi pertumbuhan ikan Lele Sangkuriang berkisar antara $25-30^{\circ} \mathrm{C}$. Kemudian $\mathrm{pH}$ selama pemeliharaan berkisar antara 6.37.5, berdasarkan pernyataan Sarwono (2011) pH optimal untuk pertumbuhan ikan Lele Sangkuriang berkisar $7 \quad-8$. DO berkisar antara 4.4- $5.5 \mathrm{mg} / \mathrm{L}$, TSS 0,157 0,402 dan Ammonia 3,22 - 5,02 ml/L. Menurut Huet (1975) dalam Safitri A (2014) oksigen minimal yang dibutuhkan oleh ikan Lele Sangkuriang sekitar 3,0 $\mathrm{mg} / \mathrm{L}$. TSS 0.157-0.420 ml/L dan Amonia 3.39-4.97 $\mathrm{ml} / \mathrm{L}$, ammonia timbul akibat kotoran ikan bisa juga di akibatkan oleh adanya pembusukan senyawa organic oleh bakteri.

Dari hasil pengukuran menunjukkan bahwa nilai kualitas air berupa suhu dan $\mathrm{pH}$ setiap penyiponan masih dalam kondisi optimal yang digunakan dalam budidaya Lele Sangkuriang, untuk Oksigen terlarut selalu mengalami stabil mulai dari awal pengamatan sampai akhir pengamatan dengan rata-rata kisaran Oksigen terlarut adalah 4,4 - $5.5 \mathrm{mg} / \mathrm{L}$ ini disebabkan adanya penambahan molase pada wadah pemeliharaan, sedangkan pengukuran kualitas air berupa TSS dan Amonia setiap pengamatan menjadi meningkat, maka dalam pemeliharan rata-rata penyiponan berpengaruh terhadap kualitas air TSS dan Amoniak.

\section{Zat padat tersuspensi} merupakan tempat berlangsungnya reaksireaksi kimia yang heterogen, dan berfungsi sebagai bahan pembentuk endapan yang paling awal dan dapat menghalangi kemampuan produksi zat organik di suatu perairan.

TSS tidak hanya menjadi ukuran penting erosi di alur sungai, juga berhubungan erat dengan transportasi melalui sistem sungai nutrisi (terutama fosfor), logam, dan berbagai bahan kimia industri dan pertanian (Anonymous, 2002), maka dari itu di lakukan penyiponan dalam sistem bioflok untuk mengurangi berbagai bahan kimia atau logam, zat merugikan pada wadah pengamatan.. Penyiponan yang berdeda pada setiap perlakuan untuk mengurangi TSS dan amoniak yang ada dalam wadah pengamatan sehingga bisa menentukan yang terbaik. Dalam pegamatan ini penyiponan yang terbaik adalah perlakuan penyipona $45 \%$. Penggantian air/penyiponan ini dilakukan secara berkala. Jangan terlambat dilakukan saat kondisi sudah ektrem penggantian air hendaknya dilakukan hanya (30\%) - (40\%) dari jumlah air wadah.

\section{KESIMPULAN}

Penyimponan terhadap pertumbuhan ikan Lele Sangkuriang (Clarias gariepinus) pada sistem bioflok berpengaruh sangat nyata terhadap pertumbuhan berat mutlak, panjang mutlak, konversi pakan, efisiensi pakan dan kelangsungan hidup Ikan Lele Sangkuriang(Clarias gariepinus).

Penyimponan yang terbaik terdapat pada penyimponan $45 \%$ dengan kelansung hidup mencapai $98,41 \%$ rata-rata oksigen terlarut $5,5 \mathrm{mg} / \mathrm{L}$, TSS $0,225 \mathrm{ml} / \mathrm{L}$ dan amnia 3,65. 


\section{DAFTAR PUSTAKA}

Anonymous. 2002. Konsumsi Penduduk Jawa Timur. Surabaya :Badan Pusat Statistik Propinsi Jawa Timur.

Avnimelech Y. \& Kochba M. 2009. Evaluation of nitrogen uptake andexcretion by tilapia in bio floc tanks, using $15 \mathrm{~N}$ tracing.Aquaculture 287:163-168.

Crab R, Avnimelech Y, Defoirdt T, Bossier P, Verstraete W. 2007. Nitrogen removal techniques in aquaculture for sustainable production. Aquaculture 270: 1-14.

Craigh S. \& Helfrich LA. 2002. Understanding Fish Nutrition, Feeds, and Feeding, Viginia Coperative Extension Service. Publication 420256: $1-4$.

Effendi, H. (2003).Telaah Kualitas Air Bagi Pengelolaan Sumber Daya dan Lingkungan Perairan. Yogyakarta: Kanisius. Halaman.168-169.

Gunadi,

B.\&Hafsaridewi,

R. 2007.Pemanfaatan Limbah Budidaya Ikan Lele (Clarias gariepenus) Intensif Dengan Sistem Heterotrofik Untuk Pemeliharaan Ikan Nila.Laporan Akhir Kegiatan Riset 2007 Sukamandi:Loka Riset Pemuliaan dan Teknologi Budidaya Perikanan Air tawar. 18 hal.

Hanafiah .A. K. 2010.Rancangan Percobaan. Fakultas Pertanian Sriwijaya Palembang.Rajawali pers. Edisi Ketiga.

Hendrawati, R. 2011. Pemanfaatan Limbah Produksi Pangan dan Keong Mas (Pomacea canaliculata) sebagai Pakan untuk Meningkatkan Pertumbuhan ikan Lele Dumbo (Clarias gariepinus). Surakarta. Universitas Negeri Surakarta.

Pardiansyah, D. 2014. Pemanfaatan Limbah Budidaya Ikan Lele (Clarias Sp) Sistem Bioflok Untuk Budidaya Cacing Sutra
(Tubificidae).Tesis.Program Studi Ilmu Akuakultur Institut Pertanian Bogor.

Pardiansyah, D, Eddy S, Daniel D, 2014.Evaluasi Budidaya Cacing Sutra Yang Terintegrasi Dengan Budidaya Ikan Lele Sistem Bioflok. Jurnal Akuakultur

Salamah. 2014, Kinerja Pertumbuhan Ikan Lele sangkuraing (Clarias Gariepinus) Yang Di Kultur Pada Sistem Bioflok dengan Penambahan Bakteri Heterotrofik Isolat L1k. Bogor

Widanarni. 2012. Evaluation of Biofloc Technology Application on Water Quality and Performance of Red Tilapia Oreochromis sp. Cultured at Different Stocking Densities.Institut Pertanian Bogor. Hayati Journal of Biosciences.

Yulfiperius. 2014. Nutrisi Ikan. PT Raja Grafindo Persada. Jakarta 